\title{
IMPLEMENTING GLOBAL ENVIRONMENTAL STANDARDS: IS THE NON-STATE SECTOR A RELUCTANT CONVERT OR AN EAGER DEVOTEE?
}

\author{
Palitha T.B. Kohona*
}

\section{BACKGROUND}

The international community has over a period of time been developing standards to deal with a range of environmental issues, some global and some regional ${ }^{1}$ The setting of contemporary international environmental norms received a major boost with the United Nations Conference on the Human Environment (Stockholm 1972). ${ }^{2}$ The Stockholm Declaration contributed to clarifying a number of principles which may subsequently have acquired customary international law status. The process of developing global environmental standards gathered further momentum with the Rio Summit which resulted in the Rio Declaration, ${ }^{3}$ and with the Johannesburg World Summit on Sustainable Development. ${ }^{4}$ In parallel with (and sometimes ahead of) the development of global standards, countries have been both adopting a wide array of environment-related domestic policies and enacting legislation. The environment is no longer an issue that concerns only focused pressure groups and other nonmainstream entities seeking to achieve their narrowly defined goals through specifically defined actions, in particular in the developed countries. ${ }^{5}$ It is a concern for most individuals, civil society and to corporations, to varying extents, and is a

* LL.B (Sri Lanka); LL.M (Australian National University); Ph.D (Cambridge, UK); Chief, Treaty Section, Office of Legal Affairs, United Nations. The views expressed in this paper are the author's own unless otherwise indicated.

${ }^{1}$ See, Guruswami, L.D., Palmer, G.W.R., Weston, B.H., and Carlson, J.C., International Environmental Law and World Order (Westgroup, 1999).

${ }^{2}$ Stockholm Declaration, http://www.unep.org/DPDL/Law/PDF/Stockholm_Declaration.pdf; See also Brown Weiss, E, "Our rights and obligations to future generations for the environment", 84 AJIL (1990) 198.

3 United Nations publication, Sales No. E.73.II.A.14 and corrigendum.

${ }^{4}$ A/CONF.151/26 (Vol. I); http://www.un.org/documents/ga/conf151/aconf15126-1annex1.htm

5 Kohona, P.T.B., "The role of non state entities in the making of international norms and their implementation", IJWI (September 2001).

Asian Yearbook of International Law, Volume 11 (B.S. Chimni et al., eds.)

(C) 2006 Koninklijke Brill NV. Printed in The Netherlands, pp. 69-88. 
mainstream political issue in most developed countries. " "The environment" is also defined in a wider sense. While public pressure ensures that the environment continues to occupy the political centre stage in developed countries, developing countries are also beginning to pay greater attention to it for a range of reasons.

The ascendancy of the environment to the centre of the political stage has much to do with the growing acknowledgement of the impact of human activity on the environment and, in turn, its increasing effect on the lives, health, and wellbeing of individuals and communities, and of the business activities of corporations. ${ }^{7}$ The environment and any changes to it have an impact on humans, animals, plants, and people's livelihoods in ways that are only now beginning to be better appreciated. In recognising some of the negative consequences of human activity on the environment, states have concluded a large number of multilateral agreements incorporating a complex range of global standards to address a variety of environment-related issues. Over 250 of these agreements, both regional and global, ${ }^{8}$ have been concluded, of which more than fifty-five are deposited with the Secretary General of the United Nations. ${ }^{9}$ Many non-binding international instruments have also been concluded. ${ }^{10}$ Some elements in these non-binding instruments may have achieved customary international law status. ${ }^{11}$ Ensuring compliance with these global standards ${ }^{12}$ -

${ }^{6}$ In a major policy statement in September 2004, Prime Minister Blair said that he would make global warming a centrepiece of the UK's presidency of the G8 group of industrialised nations next year (2005), in his speech to the Prince of Wales's Business and the Environment charity, "Blair urges world to act over global warming", Financial Times, Internet Version at FT.com (23 September 2004).

7 "Climate change in the Arctic is a reality now", Dr. R. Corell, Head, Arctic Climate Impact Assessment Group, as reported in The Economist (13 November 2004), at 87.

8 Among the key global agreements are: Convention on Biological Diversity, 1992, 1760 UNTS 79; United Nations Framework Convention on Climate Change, 1992, 1771 UNTS 107; Kyoto Protocol to the United Nations Framework Convention on Climate Change, 1997, Depositary Notification C.N.101.2004.TREATIES-1 of 11 February 2004; Convention on the Transboundary Effects of Industrial Accidents, 1992, 2105 UNTS 457; Stockholm Convention on Persistent Organic Pollutants, 2001, Depositary Notification C.N.531.2001.TREATIES-96 of 19 June 2001; Vienna Convention for the Protection of the Ozone Layer, 1985, 1513 UNTS 293; Montreal Protocol on Substances that Deplete the Ozone Layer, 1987, 1522 UNTS 3; United Nations Convention to Combat Desertification in those Countries Experiencing Serious Drought and/or Desertification, Particularly in Africa, 1994, 1954 UNTS 3 (all texts are also available on untreaty.un.org).

9 See Multilateral Treaties Deposited with the Secretary-General, U.N Doc. ST/LEG/SER.E...; Also available at http//untreaty.un.org.

10 The most prominent among these would be the Stockholm Declaration, http://www.unep.org/DPDL/Law/PDF/Stockholm_Declaration.pdf; Rio Declaration of the United Nations Conference on Environment and Development, A/CONF.151/26 (Vol. I), http://www.un.org/documents/ga/conf151/aconf15126-1annex1.htm.

${ }^{11}$ See, Lachs, M. "The general development and trends of international law in our time", 169 Recueil des Cours (1980-IV) at 175 et seq.

12 Among the principles that were developed include the following: "The environment is the Common Concern of Humankind", "Intergenerational Equity", "The Precautionary Principle", "GoodNeighbourliness", "Common but Differentiated Responsibility", "The polluter pays principle", "The Principle of Cooperation in Scientific Research, Systematic Observations, and Assistance". Whether 
not only by states, but in the modern context, also by non-state entities - has been a major issue.

Historically, governments and international organizations were required to play the dominant role in the implementation of internationally agreed norms. ${ }^{13}$ Over time there was a gradual realization that other actors needed to be engaged in this exercise and other options explored, not only because of the political and financial limitations that had begun to constrain the actions of governments and international organizations, but also because of the realization of the significant position in society occupied by these other entities. Resources were also needed to be sourced from elsewhere. Accordingly, considerable effort has been expended in recent times in encouraging non-governmental entities to become more closely engaged in giving effect to internationally agreed environmental standards. For many non-state entities, in particular for those in the private sector, this was a novel experience and, for some, one that seemed to conflict with their normal core activities. NGOs have, for some time, been raising their profile in contributing to the implementation of global environmental norms. As Kofi Annan, Secretary General of the United Nations, has observed,

\begin{abstract}
We live in an era in which international affairs are no longer dominated by States as the sole actors. The participants include non-governmental organisations, national parliaments, private companies, the mass media, universities, intellectuals, artists, and every woman and every man who considers him or herself to be part of the great human family. ${ }^{14}$
\end{abstract}

As the enthusiasm for giving effect to global environmental norms has grown, an increasing number of private sector corporations have entered the environmental arena. The United Nations has heartily encouraged this tendency. The Global Compact targeted at the private sector and developed under the leadership of the UN Secretary General, states in Principle Eight that "[they] should undertake initiatives to promote greater environmental responsibility". ${ }^{15}$

\title{
2. INTERNATIONAL ORGANIZATIONS
}

Treaty provisions are essentially directed at state parties; environmental treaties are no exception. However, many environmental treaties by their very nature have an impact on the lives of individuals and the business activities of corporations, thus requiring states to adopted detailed domestic legal and policy measures to give effect

\footnotetext{
some or all of these have attained customary international law status continues to be debated.

13 International law recognizes that only states and international organizations could be parties to treaties.

14 "Introduction", United Nations Directory of Non Governmental Organisations Associated with the Department of Public Information (1997-1998); also see Kohona, n. 6.

15 www.unglobalcompact.org.
} 
to their treaty obligations. ${ }^{16}$ While compliance by states with their treaty obligations in treaties that have entered into force is obligatory, and many states readily give effect to their treaty obligations, others may require assistance in this respect. ${ }^{17}$ It is usual for environmental treaties to contain provisions requiring assistance to be provided to those states that need assistance with the implementation of their obligations. ${ }^{18}$ Developing countries are usually the beneficiaries of such provisions.

While bilateral assistance has been important, intergovernmental organizations have, historically, played an important role in providing financial and technical assistance to developing countries for the latter to comply with their treaty-based obligations. This has also been true of environmental treaties. Since international organizations have always depended on the goodwill of donor governments, their policy approaches have largely been a reflection of the priorities of such governments. Donor governments, under constant pressure from their own constituencies, particularly from the environmental lobby groups, have assiduously sought to influence policy formulation by international organizations with a view to having their own environmental and social concerns (perhaps, even, economic concerns) reflected in the policies. It could be said that donor governments, while in the process of implementing their own obligations under multilateral treaties, have also sought to influence developing countries' environmental and development policies through the mechanism of bilateral aid and multilateral donor agencies. ${ }^{19}$ For example, it is today almost impossible for multilateral lending organizations, which themselves are not party to the multilateral environmental agreements, to fund projects in a developing country without ensuring the execution of an environmental impact assessment.

The policies of international organizations have undergone considerable change over the years; efforts to exert influence on private sector corporations and particularly on financial institutions, have become a part of their strategy. It is also noted that the policy framework set by certain intergovernmental organizations, in particular by the World Bank (Bank) and the International Monetary Fund (IMF), has played an important role in influencing decision making by private sector corporations, especially in the areas of the environment and social policy.

Although the Bank is not a party to the multilateral environmental agreements, ${ }^{20}$ the extent to which multilateral environmental norms have begun to influence the

\footnotetext{
16 Kohona, P.T.B., "The international rule of law and the role of the United Nations", 36 The International Lawyer (Winter 2002) 1131, at 1133.

17 See Art. 26, Vienna Convention on the Law of Treaties, untreaty.un.org; also see the offer of assistance made by the UN Secretary-General in his letter to heads of state and government inviting them to the Millennium Summit Treaty Event, DPI/2130.

${ }^{18}$ See for example, Art. 11, Kyoto Protocol to the United Nations Framework Convention on Climate Change, (Kyoto Protocol) untreaty.un.org. Art. 11 requires developed country parties and other developed parties included in Annex II to the Convention to provide new and additional resources and assist with the transfer of technology to developing countries.

19 NGOs also play a prominent role in influencing the policies of multilateral donor agencies.

${ }^{20}$ Art. 13(8) of the Kyoto Protocol makes provision for the United Nations, its specialized agencies and the International Atomic Energy Agency to be represented at sessions of the Conference of Parties.
} 
Bank is illustrated by the way global environmental standards and their implementation have become part of its policy framework. ${ }^{21}$ While these standards may not be linked directly to any specific multilateral agreement, they seek to reflect the thrust of these agreements and affect the environment of recipient countries in a positive manner. ${ }^{22}$ The Bank has established an environmental department and a five-year strategy on "Environment, Growth and Development". Consistent with its policy, ${ }^{23}$ it will determine whether an environmental impact assessment (EIA) is necessary when disbursing financial assistance. ${ }^{24}$ The criteria developed by the Bank and its affiliates provide a valuable yardstick for assessing the activities of private sector corporations. It is noted that the Bank, which allocated \$200 Million for energy efficiency and renewable energy projects, has agreed to increase this amount annually (the annual target is 20 per cent) over the next five years. ${ }^{25}$ Although it did not agree with the recommendation in the Extractive Industries Review that it cease funding oil, gas and mining projects, ${ }^{26}$ past experience suggests that, in the future, it is likely further to tighten its environmental and social policy approaches, as these affect extractive industries. ${ }^{27}$ In turn, given the influence of the Bank in arranging project financing in developing countries, there will be a flow-on effect on private sector institutions that provide financing in these areas. The International Finance Corporation (IFC), which finances development projects and is the private sector

${ }^{21}$ Member states of the Bank who are party to these environmental agreements and NGOs have been largely responsible for this development.

${ }^{22}$ It may even be time to consider encouraging intergovernmental lending institutions to become directly active in the multilateral environmental agreements through an appropriate mechanism although at the time that these agreements were negotiated only the European Community was considered as a prospective member. These lending institutions play a critical role in the realization of the goals of these multilateral environmental agreements; active participation in their governing fora may result in a more effective cross fertilization of policies and approaches. In addition, such an innovation might lead to a greater consistency between policies and approaches of intergovernmental financial institutions, on the one hand, and the goals sought to be achieved by these multilateral environmental agreements, on the other.

${ }^{23}$ See generally, Making Sustainable Commitments: An Environment Strategy for the World Bank, 2001 , at http:ht//lnweb18.worldbank.org/ESSD/envext.nsf/41ByDocName/EnvironmentStrategyStrategyA tAGlance.

24 While the multilateral environmental agreements do not contain detailed provisions on best environmental practices, the Bank's approach has been influenced by the practices of those states parties to these agreements who are also members of the Bank.

25 Bank to Go On Financing Coal and Oil Projects, New York Times, 4 August 2004 (Internet edition). A review of the Bank's role in mining, oil and gas industries headed by Emil Salim (Striking a Better Balance - The World Bank Group and Extractive Industries: The final Report of the Extractive Industries Review, 4 June 2004) had recommended that the Bank cease funding those industries by 2008; See comment in, 11 (114) IPS UN Journal (23 June 2004), at 1.

${ }^{26}$ The Bank's position was largely strengthened by the support it received from developing countries.

27 While, not directly stated, the Bank's policies with regard to renewable energy would contribute considerably towards realizing the goals of the Kyoto Protocol, untreaty.un.org. 
lending arm of the World Bank Group ${ }^{28}$ developed the Equator Principles in 2003; these are applicable to certain categories of project financing. ${ }^{29}$ The Equator Principles have inevitably been influenced by Bank policies on environmental and social issues. Several major public and private sector institutions take their cues on social and environmental standards from the IFC. ${ }^{30}$ The credit group of the Organisation for Economic Cooperation and Development has been moving closer to the IFC's guidelines. ${ }^{31}$

The Global Environmental Facility (GEF), constituted by the World Bank, the United Nations Environmental Programme (UNEP), and the United Nations Development Programme (UNDP), is another major facility providing multilaterally sourced funding for the realization of global environmental standards consistent with the objectives of a number of multilateral environmental treaties. Originally conceived as a mechanism for giving effect to the Montreal Protocol to the Vienna Convention on the Protection of the Ozone Layer, ${ }^{32}$ the GEF has 172 State partners and has, so far, disbursed $\$ 4.5$ billion for various environment-related projects in developing countries. The GEF has been designated the financial mechanism for biodiversity, climate change, and persistent organic pollutants. It also supports projects for combating desertification, and the protection of international waters and the ozone layer.

The United Nations Development Programme (UNDP), the main development funding programme of the United Nations, provides resources for environmentally friendly development. ${ }^{33}$ It insists on EIAs when disbursing certain categories of development assistance. UNDP policies also tend to influence its private sector collaborators. The UNDP also plays a significant role in providing training and capacity building.

The United Nations Environment Programme (UNEP), which has the primary responsibility for global environmental policy formulation, also plays a valuable role in facilitating the implementation of global environmental norms. It also focuses on training and capacity building. UNEP arranges technical assistance to developing countries, yet the funding for such assistance comes primarily from bilateral or multilateral donors. ${ }^{34}$ The UNEP, which has suffered in the past due to the suspicions harboured by donor countries with regard to its ability to be effective, still has much potential to realize.

\footnotetext{
28 The IFC has provided $\$ 16.8$ billion for project financing since 2003.

29 See below for further details on the application of the Equator Principles.

${ }^{30}$ See for a critical review, Balls, A., "World Bank 'weakening' social safeguards", Financial Times, 3 September 2004 (Internet version).

3111 IPS UN Journal (No. 154, 19 August 2004), at 1.

32 See untreaty.un.org.

33 www.undp.org.

${ }^{34}$ Walde, T.W., "The role of selected international agencies in the formation of international energy law and policy towards sustainable development", in Bradbrook, J. and Ottinger, R. (eds.), Energy Law and Sustainable Development, IUCN Policy and Law Paper, No. 47(2003), 171 at 190.
} 
Increasingly, bilateral aid donors are also insisting on environmental conditions, in particular EIAs, when providing project aid. Donors are themselves driven by the demands of domestic lobby groups.

\section{POLICY FRAMEWORK FOR PRIVATE SECTOR CORPORATIONS}

In addition to the direct initiatives undertaken by governments and intergovernmental organizations themselves, mechanisms are continuing to be developed to enable effective private sector participation in the implementation of the growing web of international rules on the environment. Considerable effort is now being made by governments through legislation and policy formulation, by intergovernmental agencies, and by NGOs to encourage private sector entities to play a proximate role in advancing environmental and social goals expressed in multilateral environmental and other agreements. For example, the Convention Biological Diversity ${ }^{35}$ contains detailed provisions on in situ and ex situ conservation. As will be seen later, these provisions are influencing not only legislative action by national governments but also the activities of private sector corporations.

The European Union (EU) and many of its member States party to a range of multilateral environmental agreements have been at the forefront of some of these initiatives. Each member state of the European Union listed in Annex B to the Kyoto Protocol is required to limit its emissions of the listed greenhouse gasses to the level specified. ${ }^{36}$ Article 6 of the Kyoto Protocol establishes the framework for emissions trading among Annex I parties to the United Nations Framework Convention on Climate Change; this not only enables Annex I parties to seek the assistance of each other through trading in realizing the emissions targets specified in the Protocol but also facilitates the development of a trading mechanism that could benefit private sector entities. ${ }^{37}$ With the threat of climate change looming ${ }^{38}$ and with a view to complying with the requirements of the Kyoto Protocol, the EU has taken the initiative to make emissions trading a reality ${ }^{39}$ with the enactment of the European Emissions Allowance Trading Directive, 2003. ${ }^{40}$ In a constructive effort to comply with the obligations under the Kyoto Protocol by the European Community and its member States, the EU has agreed on an emissions trading framework which com-

35 Untreaty.un.org.

${ }^{36}$ See Annex B to the Kyoto Protocol, untreaty.un.org.

${ }^{37}$ It is likely that many private sector entities will seek to benefit from this facility in the future, both as sellers as well as buyers of emissions credits.

38 After the US, which emits 20.6 per cent of the world's greenhouse gases, China is the world's second biggest, accounting for 14.8 per cent of greenhouse gas emissions in 2000, according to a Pew Centre report. This compares with 14 per cent for the European Union and 4 per cent for Japan. India made up 5.5 per cent and Brazil 2.5 per cent.

39 The European Community has competency for environmental matters.

40 www.field.org.uk. 
menced in January $2005 .^{41}$ Over 10,000 companies, including power generators, glass makers, steel producers, and cement manufacturers, will be covered by this directive. It is estimated that the carbon market within the European Community will be worth $\$ 1.5$ billion when the trading framework becomes fully operational; companies would be able to factor in carbon trading on their balance sheets. The EU established a deadline for its Member States for completing their emissions reductions plans (31 March 2004). It is currently considering legal action in the European Court of Justice against those members who missed this deadline. ${ }^{42}$ In a major policy statement, Prime Minister Blair said that he wanted to use the UK's presidency of the European Union in 2005 to push for the inclusion of the aviation industry within the EU's emissions trading scheme. Emissions from aircraft could represent a quarter of the UK's total contribution to global warming by $2030 .{ }^{43}$ The emissions trading framework would create obligations for both government and private sector entities.

The precedent set by the EU is likely to have a significant effect on its trading partners. Already Norway, Switzerland, Canada, and Japan have had formal discussions about linking to the EU system and thus creating the prospect of a hugely expanded carbon market. Some individual countries are implementing emissions trading already, e.g., the United Kingdom and Denmark. In the USA, despite the lack of enthusiasm in Washington, Chicago has established an emissions trading mechanism - the Chicago Climate Exchange (CCX). The CCX currently involves a number of major North American companies such as Dupont, BP, and the Ford Motor Company, as well as the cities of Chicago and Mexico City. The European Climate Exchange, formed in response to the regulatory framework established by the EU, brings together the CCX and London's International Petroleum Exchange. This will offer European companies a facility through which to trade emissions credits. ${ }^{44}$

The EU, consistent with the goal under the Kyoto Protocol of reducing carbon emissions, has also established a self-imposed target of producing 22 per cent of

\footnotetext{
41 The EU, as a group, ratified the Kyoto Protocol to the United Nations Framework Convention on Climate Change, 1997 on 31 May, 2002; The Russian Federation ratified it on 18 November 2004 , triggering the treaty requirements for its entry into force.

${ }^{42}$ The EC scheme is not without its critics. Some academics doubt whether such a well-functioning market will be the result of the Commission's endeavours. Professor Steve Rayner at Oxford's Said Business School and a member of the UK's royal commission on environmental pollution says: "Will there ever really be an efficient global carbon market? I seriously doubt it. The UK trading pilot scheme was a $£ 275 \mathrm{~m}$ boondoggle that attracted only a handful of meaningful participants, and even then resulted in almost no trading. International carbon trading is unlikely to develop into anything more than a much needed cover to allow for necessary subsidies and capital transfers necessary to decarbonise the energy systems of less technologically advanced countries." Financial Times, Internet Version at FT.com (22 October 2004).

43 "Blair urges world to act over global warming", Financial Times, Internet Version at FT.com (23 September 2004).

44 The Economist, 11 to 17 September 2004, at 69.
} 
energy requirements from renewable sources by $2010 .{ }^{45}$ Considerable incentives are being provided for the private sector to benefit from this initiative, which would include solar power, and wind and geothermal energy.

In addition to requiring certain companies to comply with the established emissions reduction goals within the EU, it has also taken measures to facilitate compliance with these goals by EU-based companies in their activities in developing countries. Article 12 of the Kyoto Protocol established the clean development mechanism enabling States listed under Annex 1 to the United Nations Framework Convention on Climate Change to undertake initiatives consistent with the objective of the Convention in non-Annex 1 countries. Those initiatives in developing countries meeting the criteria established under this article could be set off against the emissions reduction commitments established under Annex B of the Kyoto Protocol. A scheme has been launched for financially assisting EU companies to undertake in developing countries projects consistent with the clean development mechanism. Currently, an initiative has been launched by a number of developing rain-forest countries to have the Kyoto Protocol supplemented by an optional protocol that would enable them to participate in the carbon trading mechanism established under Article 6 of the protocol using their rain forests to acquire carbon credits. ${ }^{46}$

Many European countries have also adopted individual measures to encourage private-sector enterprises to comply with global environmental standards. The Netherlands, for example, provides tax depreciation opportunities, tax deductions, and subsidized loans for green projects. ${ }^{47}$

Although not required by the Kyoto Protocol, some developing countries have also begun to establish the framework for private sector enterprises to comply with global environmental standards, either through the adoption of appropriate policy guidelines or through actual financial and technical support. While still maintaining their negotiating position that those who have caused damage to the environment by following a harmful approach to development since the beginning of the industrial revolution, namely, the developed countries, must bear the main cost of reversing the damage, developing countries have begun to play a part in addressing the key issue of climate change. Many of the multilateral environmental agreements encourage developing countries also to contribute to the processes of addressing environmental problems, but subject to the principle of common and differentiated responsibilities. ${ }^{48}$ In addition, the attitudes of developing countries may have been influenced by pure necessity, given that a cleaner environment is more desirable than a polluted one. Increasing prosperity in some developing countries has made them more conscious of the benefits of a cleaner environment. The growing call by developed countries

\footnotetext{
45 Although it is now estimated that the EU will achieve only about 18 per cent. See 11(96) IPS UN Journal (27 May 2004), at 4.

46 This initiative places particular emphasis on the emissions reduction effect of non-deforestation.

47 Moore, C. and Ihle, J., Renewable Energy Policy Outside the United States, Renewable Energy Project Issues Brief, No. 14 (Washington, DC, October 1999).

48 Art. 10, Kyoto Protocol is applicable to developing countries also. However, it specifically makes obligations under it subject to the principle of common but differentiated responsibilities.
} 
that developing countries should also play a part in the processes of addressing environmental damage and the increasing and often hidden barriers in developed countries to products made through unacceptable environmental practices have also had their effect. For example, China has committed itself to producing ten per cent of its energy needs from renewable sources by $2010 .{ }^{49}$ China has also adopted a tough new fuel efficiency policy for motor cars. In India, the Federal Ministry for Non-Conventional Energy Sources supports renewable energy projects through the Indian Renewable Energy Agency. ${ }^{50}$ Such initiatives are unlikely to be ignored by the private sector in these countries. Brazil produces much of its electricity from biomass using sugar cane which may become a major export item in a climate of petroleum shortages. Cane is also used for the production of ethanol, which accounts for approximately 40 per cent of the fuel consumed by cars and light trucks in Brazil.

The recent rapid increase in the price of fossil fuels,${ }^{51}$ the additional cost to industry and the obvious security risks were undoubtedly the major (and welcome) motivators for the EU and China. ${ }^{52}$

\section{PRIVATE SECTOR RESPONSE}

Against a background of the expanding network of multilateral environmental norms and responding to both government policy and public pressure (and the possibility of litigation-related costs), the approaches of major corporations in many countries, particularly in industrialized countries, have begun to be influenced by international environmental standards. Other factors, such as enlightened leadership, the effect of hardening global and domestic standards, simple expediency, possible adverse effects on profits, etc., have also affected this development. As Neilson from Dow Chemicals has observed with regard to the issue of global warming, 'We are going to be in a carbon constrained world, and there's going to be a cost for carbon dioxide'. ${ }^{53}$ 'Scenario planners at Royal Dutch/Shell think that gas may surpass oil as the world's most important energy source. ${ }^{54}$ One notes that this attitude is more widespread in the European Union, Canada, and Japan than elsewhere due to a history

4911 (60) IPS UN Journal (6 April 2004), at 3.

${ }_{50}$ Mendis, M., Financing Renewable Energy Projects: Constraints and Opportunities (Silver Spring, MD: Alternative Energy Development, Inc., July 1998).

${ }^{51}$ Tricks, H. and Marsh, P., "Manufacturers face 40 per cent rise in energy bills", Financial Times, Internet Version at FT.com (17 August 2004).

52 "The rapid rise in global oil demand should lead the industrialised world to promote alternatives to oil as well as energy conservation, the International Energy Agency said on Friday", Morrison, K. and Blas, J., IEA says world must turn away from oil, Financial Times, Internet version at FT.com (11 March 2005).

${ }^{53}$ Neilson, who directs Dow Chemical's sustainable development efforts, quoted in The Economist (10 April 2004), at 53.

${ }^{54}$ Demand for gas has expanded in recent years, thanks chiefly to its greenness - it burns far cleaner than oil or coal, making it ideal for new power plants from California to China. The Economist (28 August to 3 September 2004), at 53. 
of environmental consciousness at both the social and political levels. Both Japan and the members of the European Union have been in the forefront of the environment debate as well as in participating in multilateral environmental agreements. In particular, European Community directives and legislation in individual countries have played a major role in influencing the attitudes of private sector corporations. ${ }^{55}$ In some instances, corporations have responded to public pressure and sought to comply with global standards even in the absence of legislative rules. This is a significant development since the decisions of major corporations have wide implications in the contemporary world, including on government policies and legislation. In many countries government policy tends to follow corporate attitudes. The public positions of corporations such as British Petroleum (which now prefers to describe itself as Beyond Petroleum), IBM, Ford, Alcan, Alcoa, Dow Chemicals, Cargill, and Dupont will no doubt influence governmental attitudes in due course. ${ }^{56}$ These corporations, in addition to being major investors in their respective fields, generate wealth and employment, and contribute to government revenues.

British Petroleum (BP) has developed an in-house cap and trade mechanism for its various divisions. ${ }^{57}$ While this will encourage a corporate culture of emissions consciousness, the experience that the company gains through the operation of this mechanism will stand it in good stead when it becomes necessary for BP to engage in carbon trading with other companies within the country and in the European Union in general. BP achieved its goal of reducing its 1990 emissions levels by ten per cent by 2010, eight years ahead of schedule. There was no additional cost. As Lord Browne of BP observed in "Beyond Kyoto",

Business has already found that it is possible to reduce emissions from its operations. ... Indeed, the company added around $\$ 650$ million of shareholder value, because the bulk of the reductions came from the elimination of leaks and waste. Other firms - such as electricity generator Entergy, car manufacturer Toyota, and mining giant Rio Tinto - are having similar experiences. The overwhelming message from these experiments is that efficiency can both pay dividends and reduce emissions. ${ }^{58}$

Insurers and re-insurers, consistent with concerns of those who negotiated the United Nations Framework Convention on Climate Change and its Kyoto Protocol, have begun to pay closer attention to the issue of climate change and a rise in sea levels.

\footnotetext{
55 "Regulation has spurred the creation of the ECX (European Climate Exchange). Next January, the European Union will put into effect new rules designed to curb carbon-dioxide emissions, which contribute to global warming. Major companies in the EU's 25 member states will be allowed to emit a specified amount. If they go over, they can buy credits from companies that have stayed within their limits", The Economist (11 September 2004), at 69.

${ }^{56}$ Dupont has reduced its emissions of Green House Gasses by 65 per cent compared with 1990 levels. "But multinationals like Dupont are convinced that carbon constraints are coming anyway in America, and they want to make global preparations. Since they have operations inside Kyoto-land, many are pursuing low carbon strategies at home," The Economist (9 October 2004), at 58.

57 The Economist (9 October 2004), at 59.

58 Browne, J., "Beyond Kyoto", Foreign Affairs (July/August 2004).
} 
Swiss Re, the reinsurance giant, has incorporated environmental risk into its underwriting and provides risk specific insurance products. It also encourages banks to place a higher value on those companies that are effective in their climate change risk management. Swiss Re will go "carbon neutral" over the next ten years by cutting emissions and investing in World Bank carbon sequestration projects. ${ }^{59}$ Axa, the French insurer, argues that climate risk - which it has said would affect about 20 per cent of global gross domestic product - is more important than the interest rate or foreign exchange risk. ${ }^{60}$

Citigroup which is the biggest project financier in the world has subscribed to a comprehensive environmental policy initially promoted by environmental groups to a large extent consistent with the United Nations Convention on Biological Diversity. It has agreed that this environmental policy will cover project financing affecting rain forests, indigenous areas, sensitive ecosystems, etc. It has even agreed to the concept of no-go areas.

The largest mining company in the world, Rio Tinto, which has operations on all continents except Antarctica, has formed partnerships with conservation groups such as Birdlife International. Rio Tinto sees these partnerships as a means of meeting on site the company's biodiversity goals consistent with the provisions of the Convention on Biological Diversity. ${ }^{61}$

Johnson \& Johnson has become the largest corporate user of wind power in the USA. Lafarge is reducing its emissions from its cement kilns by using innovative fuels, such as sewage treatment sludge. ${ }^{62}$

According to an assessment by the Financial Times, five per cent of global chemical sales are derived from bio-based sources today. This percentage is expected to increase to 20 per cent by 2010 . In the USA, 75 refineries produce 2.8 billion gallons of ethanol. Bio-based fuels could provide 20 per cent of electricity in OECD countries by 2020 .

London is emerging as the carbon finance capital of the world. Climate Change Capital, the first merchant bank dedicated to carbon issues, and the Carbon Trust, an innovative public-private partnership that aims to boost clean energy, in part, by funding promising technologies considered too risky for private financiers, are based there. $^{63}$

In a clear public manifestation of changed attitudes, Shell has developed mechanisms for openness and public participation, in particular of indigenous groups, in

\footnotetext{
59 Walker, C., "Carbon renewables - the role of the financial industry", A supplement to Environmental Finance, December 2004 - January 2005.

${ }^{60}$ Financial Times, Internet Version at FT.com (16 September 2004).

${ }^{61}$ See Inbaraja, S., "Business and biodiversity - risk of "greenwash"”, 12 (219) IPS UN Journal, at 4 .

${ }^{62}$ Financial Times, Internet Version at FT.com (16 September 2004).

63 The Economist (9 October 2004), at 59.
} 
its controversial Camisea Project in Peru. It maintained a publicly accessible website on developments relating to the project. ${ }^{64}$

Similarly, the Chad/Cameroon project involving ExxonMobil, Petronas and Chevron, along with the governments of Chad and Cameroon, provides another example of the developments now affecting major companies. In this case, the World Bank became a key player because of the loans it extended to the two governments to facilitate their equity participation in the project. Significant pressure was exerted by NGOs on the oil companies and the Bank to ensure that oil money was used neither to further undemocratic governance nor for the purchase of weapons. ${ }^{65}$

Many large corporations, under pressure from NGOs, have begun to produce non-financial reports relating to the impact of their activities on "environmental and social" aspects. Although many in the environmental community remain sceptical of these non-financial reports, the UNDP, with the assistance of Sustainability (a consultancy) and Standard and Poors (a credit rating agency), has begun to produce annual ratings for corporations that participate. ${ }^{66}$

Even in developing countries many corporations have become more conscious of the need to act consistently within global environmental standards. It is beginning to be acknowledged that compliance with global environmental standards does not necessarily increase costs. In fact, in many instances, it may contribute to reducing costs. For example, Kuruwita Manchester Textile Mills of Sri Lanka, a major exporter of textiles and apparel to the US market, uses a totally biological process for the treatment of its effluent. Kuruwita is the only company in the region to employ flue gas from the boiler chimney to neutralize its effluent, thereby eliminating the need for 1,000 tons of sulphuric acid annually that was previously used for neutralization. Kuruwita's enlightened attitude is reflected by many forward-looking companies in the developing world.

In many developing countries there is legislation both designed to serve environmental goals and which responds to the standards set by multilateral environmental agreements, such as the Montreal Protocol on Substances that Deplete the Ozone Layer 1987, ${ }^{67}$ the Basel Convention on the Control on the Transboundary Movements of Hazardous Wastes and their Disposal $1989,{ }^{68}$ and the Washington Convention on International Trade in Endangered Species and Wild Fauna and Flora 1973. ${ }^{69}$ Developing countries may also have legislation which simply seeks to address immediate environmental challenges such as pollution reduction, even in the absence

\footnotetext{
${ }^{64}$ Shell withdrew from the project due to guerrilla violence and because it could not secure a longterm contract for the gas at a guaranteed price. Citigroup decided not to renew its financial advising contract. Camisea is now being developed by a consortium led by PlusPetrol of Argentina.

${ }_{65}$ Useem, J., "Exxon's African adventure", Fortune (15 April 2002), at 102.

${ }^{66}$ The Economist (6 November 2004), at 64.

${ }^{67}$ Untreaty.un.org.

${ }^{68}$ Untreaty.un.org.

${ }^{69}$ Untreaty.un.org.
} 
of binding treaty obligations. ${ }^{70}$ Increasingly, such legislation is being enforced, sometimes through action undertaken by civil society. Non-compliance with environmental legislation could lead to costly litigation and adverse publicity, which corporations would very much like to avoid. Compliance with environmental standards also makes them less susceptible to public criticism. Since many developing country corporations produce goods for developed country markets, it makes economic sense to comply with global environmental standards. Not only would these assist in preventing conflict with legal requirements in the target markets; it would also help to prevent damaging protests by vigilant civil society groups. It would also make the corporations more competitive in developed country markets.

\section{PRIVATE SECTOR FINANCIAL INSTITUTIONS}

Private sector project financing is an area that is gradually beginning to comply with global environmental standards even in the absence of directly applicable treaty or domestic legal provisions. Increasingly, the import of the United Nations Convention on Climate Change and its Kyoto Protocol are beginning to be appreciated by significant segments of the financial sector. Due to a combination of factors, including pressure from NGOs and intergovernmental financial organizations, many major private sector financial institutions are beginning to pay close attention to the need to take environmental and social considerations into account in their funding and investment decisions. This is a development with potentially wide-ranging consequences which may even force the hands of governments. The views of the financial sector carry considerable weight in government circles, even in those that remain to be convinced of the reality of climate change and global warming.

Some investors are also becoming more assertive about the potential risk posed by climate change to their portfolios. The Australian Commonwealth Superannuation Scheme, which controls a substantial fund, has incorporated sustainability principles into its risk management with regard to its long term investments. ${ }^{71}$ In the US, thirteen public pension fund leaders managing assets of nearly $\$ 800$ billion called on the Securities and Exchange Commission to "eliminate any doubt" that companies should be disclosing the financial risks of climate change in their securities filings. ${ }^{72}$

Corporations of this nature can exercise significant influence on the decisions made by the institutions with which they place their funds. An environmentallyconscious fund could engage in "environmental shopping" thereby exerting pressure on banks and other financial institutions to comply with its own standards.

The IFC developed the Equator Principles in collaboration with major banks; these principles have now attracted the participation of a number of global banks.

\footnotetext{
70 It is noted that the United Nations Framework Convention on Climate Change 1992 and the Kyoto Protocol 1997 do not create binding commitments relating to GHG (Greenhouse Gas) reduction for developing countries.

71 www.css.gov.au.

72 Financial Times, Internet Version at FT.com (16 September 2004).
} 
Under the Equator Principles, implementation of which is voluntary, banks commit themselves not to "provide loans directly to projects where the borrower will not or is unable to comply with our environmental and social policies and processes". ${ }^{73}$ Twenty-eight major banks have already subscribed to these and the number has increased gradually. Among the banks listed as having subscribed to these principles are ABN Amro, Westlb, Royal Bank of Canada, Credit Suisse Group, Citigroup, Dresdner Bank, Westpac, and Banco Bradesco S.A. The Equator Principles apply globally. They relate to project financing and specifically to investments above $\$ 50$ million. They cover all industry sectors, including mining, forestry, oil, and gas. The Principles would require banks to undertake environmental assessments prior to decision making affecting project financing, which would address issues such as the impact on natural habitat, implications of involuntary resettlement, and effects on indigenous peoples and communities. Subscription to the Equator Principles by a bank attracts IFC endorsement of the project concerned and is an important element in encouraging participation by other financiers. It is estimated that the banks that have subscribed to them are responsible for 30 per cent of project loan syndication. IFC involvement also contributes to higher standards of governance. The IFC provides training to banks on these principles.

\section{REASONS FOR THE CONVERSION - FAITH OR NECESSITY?}

The reasons for the gradual conversion of the decision makers of an increasing number of private sector institutions to adopting environmental friendly policy approaches are interesting, given their traditional focus on profits and the obsession with year-end bonuses. Undoubtedly, the global environmental standards incorporated in a range of treaties have been a major factor: not only did these result in the development of a network of broadly accepted universal standards and raised awareness, but also caused the enactment of domestic legislative and policy measures. ${ }^{74}$ The availability of global standards enabled civil society, using them as benchmarks, to mount campaigns to exert pressure on governments and corporations. Against the strengthening framework of legal measures, the message preached by civil society groups and academics for some time - that non-compliance with global environmental standards carries financially negative consequences - may also finally be getting through. In fact, non-compliance with global environmental standards may actually result in the loss of profits and bonuses, and this has been a powerful element in focusing the minds of those making critical corporate decisions.

Undoubtedly, the growing environmental political activism world-wide, which has increasingly become more closely oriented towards results, has been a critical factor. Environmental activism is likely in the future to gather further momentum rather than to diminish. In the US, Senators McCain and Lieberman have tabled a

73 Preambular paragraph 5, Equator Principles, at www.equator-principles.com.

74 European Emissions Allowance Trading Directive, www.field.org.uk. 
bill that will impose federal restrictions on Greenhouse Gas (GHG) emissions. ${ }^{75}$ Although repeatedly tabled without success in the Senate, this initiative might gain majority approval in time; it would be an unwise corporate decision maker who ignored this eventuality. Some states in the US have already begun to adopt GHG restrictions. In New England, curbs on carbon emissions from power plants are in place. They are also developing a common trading system for emissions with Canada's eastern provinces. California has legislated for such restrictions on motor car emissions to become effective in $2009 .{ }^{76}$ New York may follow suit. Given that California is one of the major markets globally for motor car producers, the US state could be expected sooner rather than later to comply with these legal requirements, with significant implications for industry standards and emissions levels. ${ }^{77}$ While such developments may not necessarily ensure US compliance at a governmental level with the caps established by the Kyoto Protocol (to which it is not a party), they will contribute to limiting the level of GHG emissions by the US and prepare the ground for US participation at some future point in emissions trading.

The continuing pressure exerted by civil society lobby groups has had a significant impact. Groups such as Greenpeace, WWF, Rainforest Action Network (RAN) and Sierra have continued to highlight corporate shortcomings and attract public attention to these. The "naming and shaming" approach adopted by such pressure groups has in some cases had a critical impact. It could be assumed that the negative publicity would harm not only the image of a company, but also its earnings. The environmental lobby group Friends of the Earth published a report (Beyond the Shine - The Other Shell Report) on the environmental damage caused by the installations of Royal Dutch Shell in Sakhalin in East Russia, in Nigeria, and in Texas. ${ }^{78}$ This report tends to contradict some of the claims publicly made by Shell. In another instance, television images of prominent individuals cutting up their credit cards issued by Citibank at the instigation of RAN may have had an impact on this bank's decision to enter into a "common understanding of key global sustainable development issues". 79 The company Home Depot changed its wood sourcing policies following a campaign carried out by environmental groups, including RAN.

Another significant and often ignored factor in the changing attitudes of the corporate sector is that many of yesterday's green activists are in pin stripes today, working in banks, other financial institutions and law firms - one famous activist from the past is now a minister of foreign affairs of a major industrial power. Unlike

\footnotetext{
75 The Economist (9 October 2004), at 58.

76 Recent scientific studies have presented an alarming view of climate change in California, suggesting that by the end of the century rising temperatures could lead to a sevenfold increase in heat-related deaths in Los Angeles and imperil the state's wine and dairy industries. These studies would further encourage environment related legislative action, see, "Study finds climate shift threatens California", New York Times, NYTimes.com (17 August 2004).

77 Toyota is already marketing a hybrid petrol/electric motor car (the Prius) which, according to government ratings, consumes petrol at an average of 60 miles per gallon. The Economist (28 August 2004), at 54.

7811 (15) IPS UN Journal, at 4.

79 'The mosquito in the tent', Fortune (31 May 2004), at 159.
} 
the executives of yesteryear, it is no longer necessary to convince these younger individuals of the worth of the environmental cause. Having grown up experiencing environmental activism, both directly and indirectly, they are already converted and need only encouragement in incorporating environmental principles into their decisionmaking processes. Environmental consciousness is particularly evident among younger executives in such places as Europe, Australia, and New Zealand.

Many major companies are increasingly taking an expansive view of their environmental responsibilities. They are not merely looking for ways to reduce their own waste, pollution, and energy usage; they are pushing their suppliers, partners and customers to do the same. In some cases these suppliers and partners may be in developing countries, encouraging compliance through economic means in those countries which are not required to undertake commitments under some of the key environmental treaties (e.g., under the United Nations Framework Convention on Climate Change). Shell and fifteen other leading mining companies have decided to treat world heritage sites as "no-go" areas for exploration purposes.

The peer pressure factor is important not only among individuals working in the corporate sector, but among corporations themselves. When a major corporation subscribes to global environmental standards, it is not uncommon for others to follow. No company wishes to be left behind or be identified as being socially irresponsible. There is also the fear of losing a carefully cultivated corporate image. "The truth is that companies adopt green practices for lots of reasons ... And they care about their reputations, which is why corporate campaigns by the likes of RAN, Greenpeace, and Friends of the Earth have an impact". ${ }^{80}$ Corporations are extremely conscious of their public image, given that a negative image could have a deleterious impact on sales and profits.

Shareholder pressure is also factor influencing corporate compliance with global environmental standards. Encouraged by civil society groups, many companies have had shareholder resolutions tabled - over 300 in the US in 2002. The Financial Times estimates that those requesting sustainability reports relevant to their investment activities receive about 20 per cent of the votes at annual meetings of shareholders. This is a percentage of shareholders that a company could not ignore other than at its own peril.

Actual litigation, including in developing countries,${ }^{81}$ encouraged by environ-

\footnotetext{
80 See ibid., at 162.

${ }^{81}$ For example, an Indonesian aid group has filed a suit for $\$ 543$ million on behalf of three villagers against the Newmont Mining Corporation, the world's biggest gold producer based in Denver, in a district court in South Jakarta, alleging that they had been made ill by mine waste dumped by Newmont in its operation at Kayut Bay, Indonesia. The fight has aroused intense interest in mining circles and among environmental groups for the concerns it raises about how multinational companies - especially those that extract resources such as coal, copper and gold as well as oil and natural gas - conduct themselves in poor nations. On 31 August 2004 an Indonesian government panel announced that Newmont 'had illegally disposed' of waste containing arsenic and mercury in the ocean near the mine site, and had failed to obtain the required permits from the Ministry of the Environment, New York Times, 8 September 2004 (Web edition); see report in the Sydney Morning Herald, 9 December 2004, 'US mining giant to face pollution trial in Indonesia'. Five executives
} 
mental and other civil society groups, has begun to play an important role in influencing corporate attitudes towards the environment. Suit was brought before US courts by plaintiffs from Myanmar and Nigeria against Shell and Unocal respectively for breaches or connivance in breaches of human rights. ${ }^{82}$ The Unocal case, which subsequently travelled a tortuous route, was settled out of court. It was based on a law passed by Congress in 1789 awarding the district courts jurisdiction over any civil action by a foreigner against a person on US territory for acts committed abroad in violation of the law of nations or a treaty to which the USA is a party. (This law was originally designed to combat piracy.) Unocal was alleged to have been implicated in the violation of human rights by Myanmar soldiers during the construction of an oil pipe line in Myanmar. It is important that the violation of human rights standards established mainly under the International Covenant on Civil and Political Rights $1966^{83}$ by the agents of a foreign government could have been used to base a claim for legal liability before a US court. A significant implication of this approach is the possibility of other American corporations' being sued in the US for the violation of universal human rights principles or established environmental principles by a collaborating governmental authority of a foreign country acting to advance the interests of such American entities. ${ }^{84}$

There is litigation pending in Ecuador involving ChevronTexaco concerning environmental- and health-related harm caused by the dumping of toxic wastes and crude oil by the company in its Ecuadorian operation. After a battle lasting over ten years, US courts have held that the Ecuadorian courts had primary jurisdiction in this matter, which concerns claims by indigenous groups on the basis of forum non conveniens. Although the objections to and the litigation involving the Karahnjukar Power Plant in Iceland funded by Barclay's Bank of the United Kingdom took four years to resolve, the eventual judgement permitted the construction of the plant. ${ }^{85}$ The Baku-Ceyhan Pipeline Project managed by British Petroleum and funded by a range of private banks, multilateral financial institutions such as the IFC, and governments is being challenged before a range of judicial institutions. ${ }^{86}$ Cases are pending before the European Court of Justice, the Georgian Court of Abandonment, and the European Court of Human Rights involving a complexity of issues, including breaches of the Equator Principles. ${ }^{87}$

working for US gold mining giant Newmont were to stand trial in Indonesia in early January 2005 over pollution allegations.

82 Doe I v. Unocal, 110 F. Supp.2d. 1294 (C.D. Cal. 2000). Here the court held that Unocal could not be held liable for Myanmar's use of forced labour due to its lack of control over the actions of the Myanmar government. In Ken Wiwa v. Royal Dutch Shell Pet. Co. 226 F.3d 88 (2d Cir. 2000) the court upheld US jurisdiction over a claim that Royal Dutch Shell had provided money, weapons, etc. to the Nigerian military, which committed human rights violations.

83 See untreaty.un.org.

84 See report, 'US oil giant settles suits on Burma abuses', 12 (230) IPS UN Journal, at 4.

85 The Equator Principles featured in the claim advanced by the Icelandic Nature Conservation Association.

86 The Equator Principles have been discussed also in the context of this dispute.

87 www.ifc.org/btc. 
Such litigation is time consuming and costly. ${ }^{88}$ Where the damage is clear, the plaintiffs are certain responsibility could be traced, jurisdictional issues could be determined within a recognized framework, and the legal rules are clear, litigation involving breaches of environmental norms may proceed in a predictable manner. However, given the uncharted nature of some of the issues in the environmental arena, litigation might provide an interesting challenge to lawyers. The clarification of the legal rules may take time thus in many instances, a project could be held up for years by litigation. Royal Dutch Shell is facing legal challenges arising from its alleged violations of environmental standards in Manila in the Philippines, Sao Paulo in Brazil, and Texas in the US. ${ }^{89}$ Many major corporations would rather not be confronted by litigation that could be avoided in the first place through their adequate compliance with environmental norms.

The possibility of shareholder litigation against directors for acting culpably by not taking adequate action to avoid climate change-related consequences of their actions has also been raised. The Overseas Private Investment Corporation and the Export Import Bank were in 2002 sued by Friends of the Earth, Greenpeace, and the City of Boulder. The former agencies were accused of failing to conduct environmental reviews in accordance with the National Environmental Policy Act before financing fossil fuel projects, worth over \$32 billion, that contribute to global warming. ${ }^{90}$ Similarly, the US Environment Protection Agency was sued by the states of Maine, Connecticut, Massachusetts, et al. in 2003 under the Clean Air Act for failure to regulate carbon dioxide emissions. ${ }^{91}$

Projects could be closed down for contravention of environmental rules or by endless protests. These would impact negatively on the profitability of a corporation.

What does this all mean? There exists a clear likelihood of cost overruns. Essentially, these are elements that have a serious impact on the bottom line: on profits and bonuses.

\section{CONCLUSIONS}

It is probably premature for environmental activists to declare victory in their efforts to encourage environmental responsibility in the decision-making processes of private sector corporations. Much more work remains to be done especially in the area of consolidating the global framework of environmental norms and in giving effect to them within domestic jurisdictions. Efforts to obtain wider participation in the multilateral environmental treaties must continue. Universal participation will undoubtedly create a common feeling of a need to comply with the global standards incorporated in these treaties. Domestic implementation will increasingly require a higher level of uniformity and co-ordination among different states if the global standards are

\footnotetext{
88 In the US, in particular, awards could run into huge figures.

8911 (15) IPS UN Journal, at 4.

90 www.greenpeaceusa.org.

91 www.ago.state.ma.us.
} 
to be effective. Lack of uniformity could result in the dissipation through uncoordinated approaches of these standards.

Corporate compliance with the global standards, even in the absence of relevant domestic legislation, is an absolute necessity in the modern context. In the rapidly globalizing world corporations play a critical role in establishing and consolidating standards and work practices. Against this background, efforts to highlight corporate shortcomings and raise awareness must continue. Similarly, it is important further to encourage corporations that have already made the decision to adopt environmentally responsible measures. It is noteworthy that different elements of the corporate sector have begun to respond positively, to varying degrees, to the concerns of civil society. Many factors have contributed to these welcome developments; it is suggested that the dawning conviction that profits and bonuses are on the line has been a critical factor.

In addition, it is important for governments to set clear policy directions for the guidance of corporations. It may at times even be necessary for governments to assist with a helping hand. As Lord Browne of BP observes,

Offering positive incentives is one key contribution that governments can make to stimulate business. Another is organizing research. It is crucial to extend our understanding of the science of climate change: monitoring key variables with sufficient precision to understand both natural variability and the climate's response to human activity. ... [W]ith the clock ticking, we cannot wait for definite answers before we take action. ${ }^{92}$

He further states,

Government intervention must take other forms too. Transforming the energy system will require new technologies with risks that will be too high (and benefits too remote) for private firms to provide all the needed investment. This is one area in which the United States, with its outstanding technical capacity, should take a leadership role. Innovation will require an across-the-board infusion of resources for basic science and technology, as well as the development of a portfolio of key demonstration projects. ${ }^{93}$

92 Browne, loc. cit., n. 58.

93 Browne, loc. cit., n. 58. 